\title{
EFEK PEMBERIAN MADU PADA IBU HAMIL ANEMIA TERHADAP KADAR MDA, 8OHdG DAN HEMOGLOBIN
}

\author{
Andi Hariati ${ }^{1}$, Agussalim Bukhari ${ }^{2}$, Veni Hadju ${ }^{3}$ \\ ${ }^{1}$ Prodi Magister Kebidanan Sekolah Pascasarjana, Universitas Hasanuddin Makassar Indonesia \\ ${ }^{2}$ Fakultas Kedokteran Universitas Hasanuddin Makassar, Indonesia \\ ${ }^{3}$ Fakultas Kesehatan Masyarakat Universitas Hasanuddin Makassar, Indonesia
}

\begin{abstract}
Info Artikel Abstrak
Genesis Naskah:

Penelitian ini bertujuan untuk mengetahui efek pemberian madu pada ibu hamil anemia terhadap

Submissions: 19-12-2019

Revised: $31-3-2020$

Accepted: 27-5-2020 kadar malondialdehide, 8-hydroxyl-2'-deoxyguanosine dan Hemoglobin. Metode penelitian yang digunakan adalah penelitian Intervensional Pre-Post Study dengan intervensi madu pada ibu hamil trimester 3 yang anemia. Pemberian madu sebanyak 2 kali sehari selama 2 bulan dengan perbandingan kontrol. Hasil penelitian pengujian kadar malondialdehide dan 8-hydroxyl-2'deoxyguanosine dengan instrument ELISA dan pengujian kadar Hemoglobin dengan instrument

Kata Kunci:

Madu, Ibu hamil, MDA,

$8 \mathrm{OHdG}, \mathrm{HB}$

Easy Touch menunjukkan bahwa uji Paired $t$ - Test diperoleh nilai rerata malondialdehide intervensi dan kontrol masing-masing sebesar 0.001 dan 0.0.01 dengan hasil $P$ value sebesar 0.375. Sedangkan nilai rerata 8-hydroxyl-2'-deoxyguanosine intervensi dan kontrol diperoleh masing-masing sebesar 0.758 dan 0.130 dengan hasil $P$ value sebesar 0.142 . Uji kadar hemoglobin intervensi dan kontrol diperoleh nilai rerata masing-masing 0.059 dan 0.000 dengan hasil $P$ value sebesar 0.000 . Kesimpulan dari penelitian ini bahwa tidak ada hubungan intervensi madu terhadap kadar malondialdehidm, 8-hydroxyl-2'-deoxyguanosine dan Hemoglobin
\end{abstract}

\section{EFFECT OF HONEY INTERVENTION ON MDA, 8OHdG AND HEMOGLOBIN LEVEL IN ANEMIC PREGNANT MOTHERS}

\author{
Keywords: \\ Honey, Pregnant, \\ malondialdehide, 8 - \\ hydroxyl-2'- \\ deoxyguanosine, \\ hemoglobin
}

\begin{abstract}
This study aims to determine the effect of honey on amecis pregnant women on malondialdehide, 8-hydroxyl-2'-deoxyguanosine and hemoglobin levels. The research method used was an interventional pre-post study with honey intervention in anemic trimester 3 pregnant women. Giving honey as much as 1 time a day for 2 months with a comparision of controls. The results of the malondialdehide, 8-hydroxyl-2'-deoxyguanosine test testing with ELISA instrument and hemoglobin levels testing with the Easy Touch instrument showed that the Paired t-Test of malondialdehide, 8-hydroxyl-2'-deoxyguanosine levels obtained mean interventions and control malondialdehid, values respectively 0.001 and 0.001 with $P$ value of 0.375 . while the mean 8 hydroxyl-2'-deoxyguanosine of intervention and control were obtained for 0.758 and 0.130 respectively with a $P$ value of 0.142 . test levels of intervention and control hemoglobin obtained mean values of 0.059 and 0.000 respectively with a $P$ value of 0.000 . The conclusion of this study it that there is no relationship of honey intervention to malondialdehide, 8-hydroxyl-2'deoxyguanosine and hemoglobin levels
\end{abstract}

\section{Korespondensi Penulis: Andi Hariati \\ Jl. Yusuf Beauty Perumahan Citra Garden Blok F6/28 Gowa, Sul-Sel, Indonesia, Email: andihariati22@gmail.com}

(C) Poltekkes Kemenkes Jakarta I ISSN 2655-2434

Jl. Wijaya Kusuma No. 47-48 Cilandak Jakarta Selatan, Indonesia email: jurnalquality@poltekkesjakarta1.ac.id

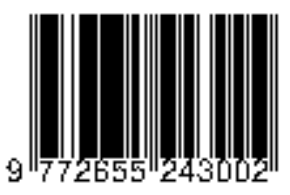




\section{Pendahuluan}

Salah satu parameter keberhasilan derajat kesehatan diantaranya adalah pelayanan kesehatan (8). Ibu hamil yang merupakan bagian dari obyek pelayanan kesehatan harus mendapatkan perhatian dan penanganan khusus dari tenaga kesehatan baik berupa konseling pendampingan, pemeriksaan kehamilan maupun pemberian treatment sebagai supplement support dan pengobatan terhadap indikasi kelainan atau gangguan kehamilan. Berbagai risiko kemungkinan didapatkan oleh ibu hamil yang menjadi penyebab langsung kematian yakni perdarahan, infeksi dan eklampsia serta penyebab tidak langsung diantaranya anemia yang pada ibu hamil disebut sebagai Potential Danger To Mother and Children (Potensial membahayakan bagi ibu dan bayi) ${ }^{(15)}$.

Upaya yang dilakukan untuk menangani pencegahan risiko pada ibu hamil antara lain melalui pemenuhan nutrisi yang kaya akan makro dan mikro nutrient. Hal ini diperkuat dengan pemikiran yang berkembang di masyarakat bahwa masa kehamilan hendaknya ibu hamil mengkonsumsi makanan sekitar dua porsi dari sebelum hamil untuk memelihara dan mempertahankan kehidupan dua orang yaitu ibu dan janin yang ada dalam rahimnya, sehingga ibu hamil cenderung tidak membatasi asupan energy sebagaimana yang telah dianjurkan ${ }^{(17)}$.

Tingginya kadar radikal bebas dalam tubuh dapat ditunjukkan oleh rendahnya aktifitas dari enzim antioksidan dan tingginya kadar malondialdehid (MDA). Malondialdehid (MDA) merupakan salah satu biomarker yang terbentuk dari peroksida lipid (lipid peroxidation) pada membran sel yaitu reaksi radikal bebas, radikal hidroksi dengan Poly Unsaturated Fatty Acid (PUFA) ${ }^{(22)}$. Komponen DNA teroksidasi, seperti 8hidroxy deoxy guanosine (8- OHdG), banyak digunakan sebagai biomarker stres oksidatif (23). Oleh karena itu penelitian ini bertujuan untuk mengetahui efek pemberian madu pada ibu hamil anemia terhadap kadar MDA, 8OHDG dan HB.

\section{Metode}

Jenis desain penelitian adalah penelitian intervensional pre-post study dan telah

(C) Poltekkes Kemenkes Jakarta I

Jl. Wijaya Kusuma No. 47-48 Cilandak Jakarta Selatan, Indonesia email: jurnalquality@poltekkesjakarta1.ac.id dilaksanakan pada bulan September - November 2019 di Puskesmas Kassi-Kassi Kota Makassar, Laboratorium Fakultas Kedokteran Universitas Hasanuddin Makassar. Sampel dalam penelitian ini adalah ibu hamil yang anemia, diambil dengan menggunakan metode consecutive sample dengan mengambil subyek penelitian yang memenuhi kriteria penerimaan sampel secara berurutan sampai besar sampel yang diinginkan terpenuhi

Sampel terdiri dari kelompok intervensi pemberian madu dan kontrol, madu diberiikan 1 kali sehari pada masa kehamilan trimester 3 selama 2 bulan dengan kriteria inklusi. Metode besar sampel menggunakan rumus dengan power $80 \%$ dan tingkat kepercayaan pada nilai $\alpha=0.05$ dengan standar deviasi (SD) 7,12 maka didapatkan sampel sebanyak 22 orang ibu hamil anak pertama, kedua, ketiga dan keempat dengan usia kehamilan trimester ketiga.

Pengolahan data dilakukan dalam tahaptahap editing, coding, processing, cleaning dan tabulating. Analisis data dilakukan dengan menggunakan program SPSS, menggunakan Paired $t$ - Test untuk data berpasangan yang terdistribusi normal, analisis bivariate dengan uji chi square dan analisis multivariate dengan multiple logistic regression, dan untuk melihat kandungan zat gizi makanan digunakan program nutrisurvey.

\section{Hasil}

\section{Analisis Univariat}

Karakteristik sampel dapat dilihat pada tabel 1 meliputi sebesaran usia, pekerjaan dan gestasi responden. Pengukuran rerata kadar HB pre-post test intervensi dan kontrol dapat dilihat pada tabel 2, didapatkan hasil bahwa pengukuran kadar HB pretest kapiler, vena intervensi dan kontrol masing-masing sebesar $9.75 \mathrm{gr} / \mathrm{dl}, 11.01$ gr/dl, $9.29 \mathrm{gr} / \mathrm{dl}$ dan $10.92 \mathrm{gr} / \mathrm{dl}$. Sedangkan hasil pengukuran kadar $\mathrm{HB}$ posttest kapiler, vena intervensi dan kontrol masing-masing sebesar 12.02 gr/dl, $12.80 \mathrm{gr} / \mathrm{dl}, 9.28 \mathrm{gr} / \mathrm{dl}$ dan $10.93 \mathrm{gr} / \mathrm{dl}$. Hasil ini menunjukkan adanya peningkatan kadar HB pada saat intervensi madu baik pengukuran darah kapiler maupun vena dengan kenaikan masingmasing sebesar $18.90 \%$ dan $6.95 \%$.

Pengukuran kadar MDA dan $8 \mathrm{OHdG}$ prepost test dapat dilihat pada tabel 3, dengan hasil yang diperoleh rerata MDA sebesar 2.2966ng/ml ISSN 2655-2434

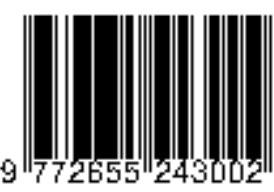


pre test dan sebesar $3.3596 \mathrm{ng} / \mathrm{ml}$ post test, sedangkan rerata kadar $8 \mathrm{OHdG}$ sebesar 33.2617 $\mathrm{ng} / \mathrm{ml}$ untuk pre test dan sebesar $36.4772 \mathrm{ng} / \mathrm{ml}$ post test.

Hasil program nutri survey untuk melihat rerata asupan gizi makro dapat dilihat pada tabel 4 . Pengujian ini dilakukan pada responden sebanyak 3 kali terdiri dari 1 kali pretest dan 2 kali post test pada hari kerja dan hari libur. Diperoleh masingmasing hasil uji untuk energy sebesar 960.1, protein hewani sebesar 24.8, protein nabati sebesar 17.8, lemak sebesar 25.4, HA sebesar 142.7. Sedangkan untuk program nutri survey hari kedua setelah intervensi madu pada hari kerja (seninjumat) diperoleh masing-masing hasil untuk uji energy sebesar 945.5, protein hewani sebesar 63.3, protein nabati sebesar 19.0, lemak sebesar 28.3, HA sebesar 993.8. dan untuk program nutri survey hari ketiga setelah intervensi madu pada hari libur (sabtu-minggu) diperoleh masing-masing hasil untuk uji energy sebesar 993.8, protein hewani sebesar 30.7, protein nabati sebesar 21.2, lemak sebesar 35.5, HA sebesar 147.9.

\section{Analisis Paired t- Test}

Tabel 7 menunjukkan hasil analisis MDA, $8 \mathrm{OHdG}$ dan HB menggunakan metode Paired $t$ test, dengan rerata kadar MDA untuk kelompok intervensi sebesar 0.925 sedangkan kelompok kontrol sebesar 0.228 maka diperoleh $P$ value sebesar 0.097 sehingga hasil $P$ value $>0.05$ maka tidak terdapat hubungan antara pemberian madu pada ibu hamil anemia terhadap penurunan kadar MDA. Dari hasil analisis rerata $80 \mathrm{OddG}$ untuk kelompok intervensi sebesar 0.736 sedangkan kelompok kontrol sebesar 0.290 dengan $P$ value sebesar 0.026 sehingga hasil $\mathrm{p}$ value $<0.05$ maka terdapat hubungan antara pemberian madu pada ibu hamil anemia terhadap penurunan kadar $80 \mathrm{OHdG}$. Dari hasil analisis rerata kadar HB diperoleh hasil $P$ value sebesar 0.000 sehingga hasil ini menunjukkan $p$ value $<0.05$ maka terdapat pengaruh intervensi madu pada ibu hamil anemia terhadap kenaikan kadar HB.

Tabel 1. Distribusi Usia Responden

\begin{tabular}{cccc}
\hline \multirow{2}{*}{ No } & \multicolumn{2}{c}{ Usia } & \multirow{2}{*}{$\%$} \\
\cline { 2 - 3 } & Range & $\mathrm{n}$ & \\
\hline 1 & $17-20$ & 3 & 13,63 \\
\hline 2 & $21-24$ & 3 & 13,63 \\
\hline 3 & $25-28$ & 5 & 22,74 \\
\hline 4 & $29-32$ & 11 & 50,00 \\
\hline
\end{tabular}

(C) Poltekkes Kemenkes Jakarta I

J1. Wijaya Kusuma No. 47-48 Cilandak Jakarta Selatan, Indonesia email: jurnalquality@poltekkesjakarta1.ac.id

$\begin{array}{ccc}\text { Total } & 22 & 100.00 \\ \text { Sumber: Data riset, } 2019 & \end{array}$

Tabel 2. Distribusi Pekerjaan Responden

\begin{tabular}{|c|c|c|c|}
\hline \multirow{2}{*}{ No } & \multicolumn{2}{|c|}{ Status Pekerjaan } & \multirow{2}{*}{$\%$} \\
\hline & Uraian & $\mathrm{n}$ & \\
\hline 1 & Tidak Bekerja & 20 & 90.90 \\
\hline 2 & Wiraswasta & 1 & 4.55 \\
\hline 3 & Pegawai & 1 & 4.55 \\
\hline 4 & Lain-Lain & - & 0.00 \\
\hline & Total & 22 & 100.00 \\
\hline
\end{tabular}

Tabel 3. Distribusi Gestasi Responden

\begin{tabular}{|c|c|c|c|}
\hline \multirow{2}{*}{ No } & \multicolumn{2}{|c|}{ Gestasi } & \multirow{2}{*}{$\%$} \\
\hline & Uraian & $\mathrm{n}$ & \\
\hline 1 & 1 & 2 & 9.09 \\
\hline 2 & 2 & 9 & 40.91 \\
\hline 3 & 3 & 11 & 50.00 \\
\hline \multirow[t]{2}{*}{4} & $\geq 4$ & - & 0.00 \\
\hline & Total & 22 & 100.00 \\
\hline
\end{tabular}

Tabel 4. Distribusi Kadar MDA

\begin{tabular}{cccc}
\hline Uraian & Kategori MDA & $\mathrm{n}$ & $\%$ \\
\hline \multirow{3}{*}{ Pre Test } & $\begin{array}{c}\text { Normal }(31.25-2000 \\
\text { ng/ml })\end{array}$ & 22 & 100.00 \\
\cline { 2 - 4 } & $\begin{array}{c}\text { Stres Oksidatif } \\
(>2000 \mathrm{ng} / \mathrm{ml})\end{array}$ & 0 & 0.00 \\
\hline \multirow{3}{*}{ Post Test } & $\begin{array}{c}\text { Normal }(31.25-2000 \\
\mathrm{ng} / \mathrm{ml})\end{array}$ & 22 & 100.00 \\
\cline { 2 - 4 } & $\begin{array}{l}\text { Stres Oksidatif } \\
(>2000 \mathrm{ng} / \mathrm{ml})\end{array}$ & 0 & 0.00 \\
\hline Jumlah & 22 & 100.00 \\
\hline & Sumber: Data riset, 2019 &
\end{tabular}

Tabel 5. Distribusi Kadar $8 \mathrm{OHdG}$

\begin{tabular}{cccc}
\hline Uraian & Kategori 8OHdG & $\mathrm{n}$ & $\%$ \\
\hline \multirow{3}{*}{ Pre Test } & $\begin{array}{c}\text { Normal }(2.3-13.8 \\
\text { ng/ml })\end{array}$ & 5 & 22.73 \\
\cline { 2 - 4 } & $\begin{array}{c}\text { Stres Oksidatif } \\
(>13.8 \mathrm{ng} / \mathrm{ml})\end{array}$ & 17 & 77.27 \\
\hline \multirow{3}{*}{ Post Test } & $\begin{array}{c}\text { Normal }(2.3-13.8 \\
\mathrm{ng} / \mathrm{ml})\end{array}$ & 1 & 4.54 \\
\cline { 2 - 4 } & $\begin{array}{c}\text { Stres Oksidatif } \\
(>13.8 \mathrm{ng} / \mathrm{ml})\end{array}$ & 21 & 95.46 \\
\hline & Jumlah & 22 & 100.00 \\
\hline & Sumber: Data riset, 2019 &
\end{tabular}

Tabel 6. Distribusi Kadar HB

\begin{tabular}{|c|c|c|c|}
\hline Uraian & Kategori HB & $\mathrm{n}$ & $\%$ \\
\hline \multirow{3}{*}{ Pre Test } & Darah Kapiler & & \\
\hline & Normal $(\geq 11.0 \mathrm{gr} / \mathrm{dl})$ & 1 & 4.55 \\
\hline & Anemia $(<$ & 21 & 95.45 \\
\hline & & N 26 & \\
\hline
\end{tabular}




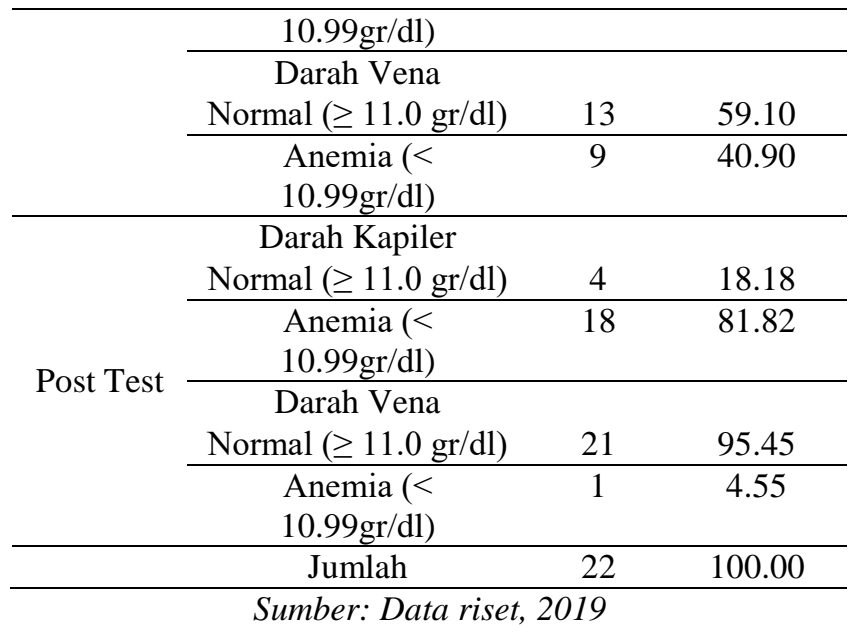

Tabel 7. Analisis Kelompok Intervensi dan Kontrol

\begin{tabular}{cccccc}
\hline Variabel & $\begin{array}{c}\text { Pretest } \\
\text { Mean } \pm \\
\text { SD }\end{array}$ & $\begin{array}{c}\text { Posttes } \\
\text { Mean } \\
\pm \text { SD }\end{array}$ & $P$ & $\begin{array}{c}\Delta \\
\text { Mean } \\
\text { SD }\end{array}$ & $\begin{array}{c}\boldsymbol{P} \\
\text { value }\end{array}$ \\
\hline MDA & & & & & \\
Intervensi & 2.2966 & 3.6476 & & 1.3510 & 0.375 \\
& \pm 0.7077 & $\begin{array}{c} \pm 2.002 \\
5\end{array}$ & $\begin{array}{c}0.001 \\
\text { \# }\end{array}$ & $\begin{array}{c} \pm 2.282 \\
5\end{array}$ & \\
Kontrol & $2.3396 \pm$ & 3.5362 & & 1.1966 & \\
& 0.6379 & \pm 0.602 & 0.001 & \pm 0.751 & \\
& & 6 & $\#$ & 1 & \\
\hline 8OHdg & & & & & \\
Intervensi & 33.2617 & 36.477 & & 3.2154 & 0.142 \\
& \pm 23.036 & $2 \pm 20.0$ & 0.758 & \pm 31.65 & $\wedge$ \\
Kontrol & 4 & 254 & $*$ & & \\
& 33.5215 & 43.134 & & 9.6129 & \\
& \pm 15.394 & $4 \pm 16.4$ & 0.130 & \pm 19.71 & \\
\hline HB & 7 & 821 & $*$ & & \\
Intervensi & $9.75 \pm 0.8$ & $12.02 \pm$ & 0.059 & $2.264 \pm$ & 0.000 \\
& 48 & 1.119 & $\#$ & 1.093 & $\#$ \\
Kontrol & $9.29 \pm 0.2$ & $10.93 \pm$ & 0.000 & 1.7854 & \\
& 89 & 0.907 & $\#$ & \pm 1.013 & \\
\hline
\end{tabular}

Sumber: Data riset, 2019

\section{Pembahasan}

Dari tabel di atas diperoleh usia responden terbanyak dikisaran 29-32 tahun dengan jumlah 11 responden. Distribusi status pekerjaan terbanyak adalah berstatus tidak bekerja dengan jumlah 20 responden dan gestasi terbanyak dengan jumlah kehamilan pertama sebanyak 11 responden. Data tersebut di atas menunjukkan hasil bahwa salah satu penyebab kejadian anemia pada ibu hamil dikarenakan faktor usia dan jumlah kehamilan yang banyak (paritas), pada trimester ketiga.

(C) Poltekkes Kemenkes Jakarta I

J1. Wijaya Kusuma No. 47-48 Cilandak Jakarta Selatan, Indonesia email: jurnalquality@poltekkesjakarta1.ac.id
Hal ini sesuai dengan penelitian (25) menunjukkan hubungan umur dengan kejadian anemia pada ibu hamil dengan nilai uji statistik terbukti signifikan $\mathrm{p}$ value $=0,012<0,005$ dengan nilai Prevalance Ratio $(\mathrm{PR})=1,8$ dan $95 \% \mathrm{CI}$ antara 1,07 - 3,28 yang artinya ibu hamil pada umur beresiko $(<20$ Tahun) berpeluang mendapatkan anemia 1,8 kali dibandingkan dengan ibu hamil pada umur tidak beresiko (20 - 35 Tahun). Berdasarkan hasil penelitian didapatkan bahwa responden dengan umur beresiko lebih banyak mengalami anemia pada ibu hamil dibandingkan responden dengan umur tidak beresiko.

Menurut peneliti hal ini dikarenakan Kehamilan diusia < 20 tahun dan diatas 35 tahun dapat menyebabkan anemia karena pada kehamilan diusia $<20$ tahun secara biologis belum optimal emosinya cenderung labil, mentalnya belum matang sehingga mudah mengalami keguncangan yang mengakibatkan kurangnya perhatian terhadap pemenuhan kebutuhan zat-zat gizi selama kehamilannya. Sedangkan pada usia >35 tahun terkait dengan kemunduran dan penurunan daya tahan tubuh serta berbagai penyakit yang sering menimpa diusia ini.

Hasil ini menunjukkan adanya peningkatan kadar HB pada saat intervensi menggunakan madu baik pengukuran darah kapiler maupun vena dengan hasil kenaikan sebesar $18.90 \%$ untuk pengukuran kadar HB darah kapiler, dan kenaikan sebesar $6.95 \%$ untuk pengukuran kadar HB darah vena.

Dari hasil tersebut diatas membuktikan bahwa intervensi madu pada ibu hamil dengan kejadian anemia dapat meningkatkan kadar HB, sehingga konsumsi madu pada ibu hamil dianjurkan sebagai salah satu alternative untuk mencegah kejadian anemia yang dapat berdampak buruk bagi ibu hamil dan janin.

Hasil rerata menggunakan Uji Independet $t$ Test bahwa intervensi madu pada ibu hamil tidak dapat menurunkan kadar MDA dengan nilai sebesar 0.375 hasil ini membuktikan bahwa $\alpha>0.05$. Dimana diketahui MDA dan $8 \mathrm{OHdG}$ sebagai biomarker kerusakan DNA dan stress oksidatif yang dapat berakibat fatal pada ibu hamil dan janin.

Pada penelitian ini didapatkan keterangan melalui wawancara langsung dengan responden bahwa kehamilan saat ini lebih cenderung 
mengalami stress yang akan berdampak pada tingginya kadar MDA tubuh diantaranya dikarenakan adanya kegagalan observasi pada kehamilan sebelumnya yakni hasil pemeriksaan tanpa USG menunjukkan hasil tidak terjadi kehamilan kembar namun pada saat persalinan didapatkan kehamilan kembar dengan salah satu bayi meninggal dunia, faktor resiko penyebab stress lainnya dikarenakan ketakutan menghadapi proses persalinan karena persalinan ini merupakan pengalaman pertama.

Pada wawancara lainnya didapatkan keterangan bahwa penyebab ibu hamil cenderung mengalami stress dikarenakan kehamilan yang kesekian kalinya dengan jumlah anak yang lebih dari 2 menunjukkan kekhawatiran akan persiapan masa depan si buah hati sehingga menimbulkan kecemasan yang berdampak pada stress menjelang persalinan.

Dari keterangan responden tersebut di atas sejalan dengan penelitian ${ }^{(9)}$ bahwa ibu hamil yang stress dapat menyebabkan kenaikan tekanan darah. Pada penderita preeklamsia terjadi suatu keadaan yang dikenal sebagai stress oksidatif dimana terjadi gangguan keseimbangan antara oksidan dan anti oksidan yang ditandai dengan meningkatnya kadar lipid peroksida (oksidan/radikal bebas) disertai menurunnya aktifitas anti oksidan. Lipid peroksida sebagai oksidan/ radikal bebas yang sangat toksis ini akan beredar di seluruh tubuh dalam aliran darah dan akan merusak membran sel endotel, keadaan ini dapat mengakibatkan terganggunya fungsi endotel bahkan rusaknya seluruh struktur sel endotel yang disebut sebagai "disfungsi endotelial (endothelial dysfunction) sehingga memunculkan gejala-gejala klinik preeklampsia. Salah satu penanda terjadinya stres oksidatif pada penderita preeklampsia adalah meningkatnya kadar lipid peroksida (MDA) ${ }^{(1)}$.

Dari hasil analisis $8 \mathrm{OHdG}$ dengan menggunakan Uji Wicoxon diperoleh kadar rerata untuk kelompok intervensi sebanyak 0.758 sedangkan untuk kelompok kontrol sebanyak 0.130 dengan $\alpha>0.05$. Hasil $P$ value yang diperoleh sebesar 0.142 dengan Uji Mann-Whitney sehingga tidak terdapat hubungan antara pemberian madu pada ibu hamil anemia terhadap penurunan kadar 8OHdG.

(C) Poltekkes Kemenkes Jakarta I

Jl. Wijaya Kusuma No. 47-48 Cilandak Jakarta Selatan, Indonesia email: jurnalquality@poltekkesjakarta1.ac.id
Adapun hasil wawancara langsung dengan responden yang berdampak pada tingginya hasil uji kadar 8OHdg tubuh adalah faktor lingkungan dan dukungan keluarga. Dimana untuk faktor lingkungan terdapat anggota keluarga serumah yang berperilaku perokok aktif yang berdampak pada cemaran udara di dalam rumah yang akan mempengaruhi kesehatan ibu hamil sebagai paparan radikal bebas, hal ini sejalan dengan penelitian (Riska dan Fariani, 2015) bahwa Berdasarkan jumlah perokok aktif yang ada di rumah dan di tempat kerja, pada kelompok kasus $(77,8 \%)$ mengatakan bahwa jumlah perokok aktif yang dekat dengan mereka di rumah atau di tempat kerja sebanyak 1-2 orang sedangkan sebagian besar kelompok kontrol $(52,8 \%)$ mengatakan tidak ada perokok aktif. Hasil analisis menunjukkan adanya signifi kansi untuk jumlah perokok aktif 1-2 orang dengan $\mathrm{OR}=5,54$, hal ini berarti ibu hamil yang berdekatan dengan 1-2 orang perokok aktif berisiko 5,54 kali mengalami anemia dibanding tidak adanya perokok aktif.

Untuk dukungan keluarga pada ibu hamil dengan jumlah kehamilan lebih dari 2 kali kurang mendapatkan dukungan dan perhatian dari keluarga khususnya suami, sehingga pada masa kehamilan rutinitas keseharian dalam rumah cenderung dikerjakan sendiri oleh ibu hamil yang berakibat pada banyaknya energi yang dikeluargan sehingga akan melemahkan fisik ibu hamil yang berpotensi terserang radikal bebas lebih besar dengan indicator tingginya kadar $8 \mathrm{OHdg}$ tubuh.

Dari hasil analisis kadar HB sampel darah kapiler dan darah vena pada ibu hamil anemia dengan menggunakan Uji Paired t- test diperoleh $\mathrm{p}$ value masing-masing kadar HB untuk darah kapiler maupun darah vena sebesar 0.000 hasil ini menunjjukan nilai $p$ value $<0.05$ sehingga dapat dikatakan signifikan terdapat pengaruh intervensi madu pada ibu hamil anemia terhadap peningkatan kadar HB.

Dari hasil diatas membuktikan bahwa madu mengandung banyak mineral seperti natrium, kalsium, magnesium, alumunium, besi, fosfor, dan kalium, ditambah lagi kandungan vitamin yang ada di dalamnya seperti thiamin (B1), riboflavin (B2), asam askorbat (C), piridoksin (B6), niasin, asam ISSN 2655-2434 
pantotenat, biotin, asam folat dan vitamin $\mathrm{K}^{(27)}$ menyebutkan dalam penelitian ilmiahnya bahwa sejak ribuan tahun yang lalu madu telah dikenal karena sifat gizi dan penyembuhannya yang menakjubkan. Madu mengandung mineral penting yang membantu dalam produksi hemoglobin. Ketika madu dikonsumsi setiap hari, penderita anemia dapat melihat peningkatkan secara signifikan dalam tingkat energi, kemudian madu membantu meningkatkan penyerapan kalsium, jumlah hemoglobin dan mengobati atau mencegah anemia karena faktor gizinya. Penelitian-penelitian terdahulu ${ }^{(24)}$ diketahui bahwa ekstra madu mampu meningkatkan kadar hemoglobin $(\mathrm{Hb})$ darah secara in vitro pada tikus putih jantan, demikian pula bahwa pemberian sari kurma mampu meningkatkan kadar hemoglobin pada tikus putih jantan galur wisata yang diberikan diet rendah zat besi ${ }^{(24)}$.

\section{Kesimpulan}

Dari hasil diatas maka ditarik kesimpulan bahwa pada pengujian kadar MDA untuk kelompok intervensi tidak terdapat hubungan penurunan kadar MDA dengan hasil $p$ value sebesar $0.375>0.05$ dan untuk pengujian kadar $8 \mathrm{OHdG}$ untuk kelompok intervensi tidak terdapat hubungan penurunan kadar 8 OHdG dengan hasil $p$ value sebesar $0.142>0.05$. Namun terdapat hubungan antara intervensi madu pada ibu hamil anemia terhadap kadar HB darah , dimana diperoleh hasil $p$ value sebesar $0.000<0.05$

\section{Saran}

Ibu hamil anemia sebaiknya diberikan intervansi madu selama 3 bulan untuk melihat efek penurunan kadar MDA dan 8OHdG yang lebih efektif dikarenakan salah satu penyebab anemia pada ibu hamil adalah paparan radikal bebas yang ditandai dengan peningkatan kadar MDA dan 8OHdR.

\section{Daftar Pustaka}

(C) Poltekkes Kemenkes Jakarta I

J1. Wijaya Kusuma No. 47-48 Cilandak Jakarta Selatan, Indonesia email: jurnalquality@poltekkesjakarta1.ac.id
Adiga U, D'souza V, Kamath A, Mangalore. Antioxidant Activity and Lipid Peroxidation in Preeclampsia. J Chin Med Assoc 2007; 70(10) : 435-438.

Almatsier, Sunita. 2011. Gizi Dalam Daur Kehidupan. Jakarta: Gramedia Pustaka Utama.

Andriani, M \& Wirjatmaji, B., 2012. Pengantar Gizi Masyarakat. Jakarta, Kencana Prenada Media Group.

Armi, 2006. Dasar-Dasar Ilmu Kebidanan. Padang, Andalas University Press

Barasi, Mary E. At a Glance. Ilmu Gizi. Jakarta: Penerbit Erlangga. 2008.

Baskhara, A, W., 2008. Khasiat \& Keajaiban Madu untuk Kesehatan dan Kecantikan. SmileBooks, Yogyakarta

Dwi Retna Prihatini, 2017. Pengaruh Multiple Mikro Nutrient. Jurnal Kebidanan Dan Kesehatan Tradisional, Volume 2, No 2, September 2017, hlm 60-115

Effendy, N., 1998. Dasar-Dasar Keperawatan Kesehatan Masyarakat. Kedokteran EGC, Jakarta

Erna Suparman, 2012. Kadar Lipid Peroksida pada Kehamilan Normotensi dan Preeklampsia. Departemen Obstetri dan Ginekologi. Fakultas Kedokteran Universitas Sam Ratulangi, Manado

Erwiyatno, L, Djoko., Krihariani, D., 2012. Pengaruh Madu Terhadap Pertumbuhan Bakteri Streptococcus pyogeneses. Analisis Kesehatan Sains 1 (1) : 30

Haider BA, Bhutta ZA. Multiple-micronutrient supplementation for women during pregnancy. Cochrane Database Syst Rev 2006;4:CD004905. PMID:17054223

Hanifa, 2005. Ilmu Kandungan, Yayasan Bina Pustaka Sarwono Prawirohardjo. Jakarta

ISSN 2655-2434

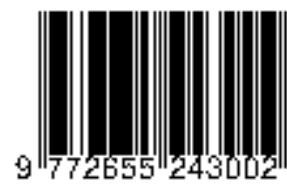


Johnson, S., Nimisha, J., 2010. Antibiotic Residues in Honey. Dalam Center for Science and Environment. Tughiakabad Institusional Area, New Delhi

Kementerian Kesehatan RI., 2017. Profil Kesehatan Indonesia Tahun 2016. Sekretariat Jenderal Kementerian Kesehatan RI, Jakarta

Manuaba, IBG., 1998. Ilmu Kebidanan Penyakit Kandungan dan Keluarga Berencana. EGC, Jakarta

Mandriawati. 2008. Penuntun Belajar Asuhan Kebidanan Ibu Hamil. EGC, Jakarta

Moore, K, R., Argur, K, M, R., 2002. Anatomi Klinis Dasar. Hipokrates, Jakarta

Mochtar, Rustam. 1998. Sinopsis Obstetry Jilid I. EGC, Jakarta

Okur, Erdogan. Malondialdehide Level and Adenosine Deaminase Activity in Nasal Polyps. Available from : http://oto.sagepuh.com/Content/134/1/137/f ull

Ojofeitimi EO, Ogunjuyigbe PO, Sanusi, et al. Poor dietary intake of energy and retinol among pregnant women. Pak J Nutr. 2008;7:48084.

Prakash, S dan Yadav, K. Maternal Anemia in Pregnancy: An Overview. International Journal of Pharmacy and Phamateutical Research Human. 2015;4(3):164-179.

Putri, Dini, R., 2014. Efek Antioksidan Fraksi Larut Etil Asetat Ekstrak Etanol Daun Jambu Biji pada Kelinci yang Dibebani Glukosa. Available from : http://www.etd.eprints.ums.ac.id/bogo/I/K10 0050059.pdf

Potdar N, Singh R, Mistry V, Evans M, Farmer P, Konje J, Cooke M. First-trimester increase

(C) Poltekkes Kemenkes Jakarta I

J1. Wijaya Kusuma No. 47-48 Cilandak Jakarta Selatan, Indonesia email: jurnalquality@ poltekkesjakarta1.ac.id in oxidative stress and risk of smallforgestational-age fetus. BJOG 2009;116:637-642.

Rio, Y, B, P., Djamal, A, Estherina. 2012. Perbandingan Efek Antibakteri Madu Asli Sikabu dengan Madu Lubuk Minturun Terhadap Eschericia coli dan Staphylococcus aureus Secara in Vitro. Jurnal Kesehatan Andalas 1 (2) : 59-62

Rohas, S.A., 2010. Faktor-Faktor yang Berhubungan dengan Anemia pada Ibu Hamil di Puskesmas Melur Kecamatan Sukajadi Pekanbaru Tahun 2010, skripsi SI Stikes Hang Tuah Pekanbaru

Soedarto. 2012. Toksoplasmosis, Mencegah dan Mengatasi Penyakit, Melindungi Ibu dan Anak. Seagung Seto, Jakarta

Suganda, J., 2015. Uji Efektivitas Madu Terhadap Salmonella thypii Secara in Vitro. Tugas Akhir

Sulistiyawati. 2009. Asuhan Kebidanan pada Kehamilan. Salemba Medika, Jakarta.

Soeprono, R., Anemia Pada Ibu Hamil. Journal Of Medical Sciences. 1988; 20(4):121-136.

Syaifuddin, H., 2002. Anatomi Fisiologi Berbasis Kompetensi Untuk Keperawatan dan Kebidanan, ECG, Jakarta

WHO. The prevalence of anaemia in 2011. WHO global database on anaemia geneva. World health organization. 2015. [cited 2015 Nov 25]. Available from: http://www.unscn.org/layout/modules /news/documents/GlobalPrevalenceA naemia2011_eng.pdf

Varney. 2007. Buku Ajar Asuhan Kebidanan Edisi 4 Volume 1. Jakarta, EGC
ISSN 2655-2434

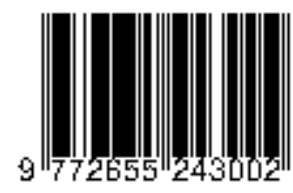

